\title{
Table of treaties and other documents
}

\begin{tabular}{|c|c|c|c|}
\hline \multicolumn{2}{|c|}{ American Treaty on Pacific Settlement } & \multirow{2}{*}{$\begin{array}{l}\text { Article } 87 \\
\text { Article } 88\end{array}$} & \multirow{2}{*}{$\begin{array}{l}160 \\
160\end{array}$} \\
\hline 1948 & 160 & & \\
\hline Charter of the & rab States & Article 89 & 160 \\
\hline 1945 & & Article 90 & 160 \\
\hline Article 5 & 162 & Article 91 & 160 \\
\hline \multicolumn{2}{|c|}{ Charter of the Organization of American } & Article 92 & 160 \\
\hline States 19 & & Article 93 & 160 \\
\hline Article 1 & $156,157,160$ & Article 94 & 160 \\
\hline Article 2 & 160 & Article 95 & 160 \\
\hline Article 3 & 160 & Article 96 & 160 \\
\hline Article 4 & 157 & Article 97 & 160 \\
\hline Article 19 & 160 & Article 98 & 160 \\
\hline Article 20 & 160 & Article 99 & 160 \\
\hline Article 21 & 160 & Article 100 & 160 \\
\hline Article 22 & 160 & Article 101 & 160 \\
\hline Article 23 & 160 & Article 102 & 160 \\
\hline Article 28 & 160 & Article 103 & 160 \\
\hline Article 29 & 160 & Article 104 & 160 \\
\hline Article 53 & 160 & Article 105 & 160 \\
\hline Article 54 & 160 & Article 106 & 160 \\
\hline Article 55 & 160 & Article 107 & 160 \\
\hline Article 56 & 160 & Article 108 & 160 \\
\hline Article 57 & 160 & Article 109 & 160 \\
\hline Article 58 & 160 & Article 110 & 160 \\
\hline Article 59 & 160 & Article 111 & 160 \\
\hline Article 60 & 160 & Article 112 & 160 \\
\hline Article 61 & 160 & Article 113 & 160 \\
\hline Article 62 & 160 & Article 114 & 160 \\
\hline Article 63 & 160 & Article 115 & 160 \\
\hline Article 64 & 160 & Article 116 & 160 \\
\hline Article 65 & 160 & Article 117 & 160 \\
\hline Article 66 & 160 & Article 118 & 160 \\
\hline Article 67 & 160 & Article 119 & 160 \\
\hline Article 68 & 160 & Article 120 & 160 \\
\hline Article 69 & 160 & Article 121 & 160 \\
\hline Article 80 & 160 & \multicolumn{2}{|c|}{ Charter of the United Nations 1945} \\
\hline Article 81 & 160 & Preamble & 14,19 \\
\hline Article 82 & 160 & Article 1 & $14,29,30,80,213$ \\
\hline Article 83 & 160 & Article 1(1) & 14,213 \\
\hline Article 84 & 160 & Article 1(3) & $29,30,80,213$ \\
\hline Article 85 & 160 & Article 2(1) & 14 \\
\hline Article 86 & 160 & Article 2(3) & xvi, 14 \\
\hline
\end{tabular}


Article 2(4) xvi, 14, 17, 19, 20, 21, 22, $23,24,25,26,27,28,29,30$, $31,33,35,38,39,40,41,44$, $80,90,98,103,114,118,119$, 120,165

Article 2(7)

Article 4(1)

Article 10

Article 11

Article 11(2)

Article 12

Article 13

Article 14

Article 17(2)

Article 24

Article 24(1)

Article 25

Article 27(3)

Article 39 147, 159

Article 40

Article 41

197

Article 42 196, 197, 200

Article 43

Article 44

Article 45

Article 46

Article 47

Article 50

Article 51 145, 198 145,198 145, 146, 197, 198 145,198 145,198 145,198

196 15 132, 200

80, 132 $132,133,134,135,146$, 197,202 $133,135,136,139,150$,

$133,136,139,146,147$, 139

139

139

139

139

137
Article 4

169

Article 4(h)

170, 171

Article 4(j)

169,170

Convention for the Pacific Settlement of International Disputes 1899

200 Preamble

18 Convention on Rights and Duties of 80, 132, 198 $15,35,41,42,43$,

$44,47,51,52,56,57,58,59$, $60,63,66,70,72,73,74,75$, $76,77,78,111,114,123,157$, $165,177,184,207,220$

Article 52 153

Article 52(1)

Article 53

Article 53(1)

153

Article 97

Article 98

Article 103

$161,177,178,187$
153,163

196

196

157,184

Consolidated Treaty of the Southern African Development Community (SADC) 2015

Article 5 172

Constitutive Act of the African Union (AU) 2000

Article 3
States adopted by the Seventh International Conference of American States (Montevideo Convention on the Rights and Duties of States) 1933

Article 1

Covenant of the League of Nations 1919 Article 10

Article 11

Article 12

Article 13

Article 15

Article 16

Article 21

8

Economic Community of West African States Treaty (ECOWAS) 1975 Article 3

General Act of the Conference of Berlin 1885

Article VI

Hague Convention II Respecting the Limitation of the Employment of Force for the Recovery of Contract Debts 1907

Article 1

Hague Convention III Relative to the Opening of Hostilities 1907

Article 1

Inter-American Democratic Charter 2001

Article 17

161

Article 18

161

Article 19

161

Article 20

161

Article 21

Article 22

161,162

Inter-American Treaty of Reciprocal Assistance 1947

Article 3

Article 6

160

Article 8

160

Article 20

161

North Atlantic Treaty (NATO) 1949

Preamble
161

165 
Article 1

Article 4

Article 5

Article 6

Article 8
157,165

165

165

165

184

Pacte d'Assistance Mutuelle entre les

Etats Membres de la CEEAC

(Economic Community of Central

African States) 2002

Article 2

Article 3

Pacte de Non-Agression entre les Etats

Membres du Comité Consultatif

Permanent des Nations Unies sur

les Questions de Sécurité en Afrique

Centrale 1996

173

Pact of Paris 1928

Article 1

Article 2

Article 3

Protocol on Amendments to the

Constitutive Act of the African

Union 2003

Para. 4(h)

170, 171

Protocol Establishing the Peace and

Security Council of the African

Union 2003

Article 2(1)

Article 7

169

Article 11

Article 12

Article 13

Article 16

Article 17(1)

Article 17(2)

Article 21

Protocol on Politics, Defence and

Security Cooperation (SADC) 2001

Article 2

Article 2(f)

Article 11(3)(d)

177

177

Protocol Relating to the Mechanism for

Conflict Prevention, Management,

Resolution, Peacekeeping and

Security (ECOWAS) 1999

Article 3

Article 22

172

172

Protocol Relating to the Mutual

Assistance on Defence (ECOWAS) 1981
Article 2

172

Article 3

172

Protocol Relative to the Council for Peace and Security in Central Africa (COPAX) (Economic Community of Central African States) 1999

Article 2

173

Protocol (No. 10), On Permanent

Structured Cooperation Established

by Article 42 of the Treaty on

European Union 2010/C 83/ 276182

Rome Statute Establishing the International Criminal Court 1998

Article 8bis

$17,133,134$

Southern African Development

Community Mutual Defense Pact 2003

Article 6

173

Standing Orders of the Central African

Multinational Force (FOMAC) 2002

Article 2

173

Statute of the International Court of Justice 1945

Article 38(1)(b) xvii

Treaty on European Union 2010

Article 3(5) 157

Article 3(5)(2) $\quad 187$

Article 13(2) $\mathbf{1 8 2}$

Article $21 \quad 157$

Article 21(1) $\quad 181$

Article 21(2) $\quad \mathbf{1 8 0}$

Article 23

Article 24(1) $\mathbf{1 8 5}$

Article 24(1)(b) $\quad \mathbf{1 8 2}$

Article 24(3) $\quad 182$

Article $25 \quad \mathbf{1 8 0 , 1 8 1}$

Article $26 \quad \mathbf{1 8 1}$

Article $27 \quad 181$

Article $28 \quad \mathbf{1 8 1}, \mathbf{1 8 2}$

Article $29 \quad \mathbf{1 8 2}$

Article $40 \quad 182$

Article $42 \quad 157,185,198$

Article 42(1) $\mathbf{1 8 0}$

Article 42(1)(3) $\mathbf{1 8 7}$

Article 42(2) $\mathbf{1 8 5}$

Article 42(4) $\quad \mathbf{1 8 1}$

Article 42(5) $\mathbf{1 8 2}$

Article 42(6) 182

Article 42(7) $\quad \mathbf{1 8 4}, 185$

Article $43 \quad \mathbf{1 8 5}, 198$ 
Article 43(2)

Article 45

Article 46

Article 275

Treaty on the Functioning of the

European Union 2010

Article 222

Article 351

Treaty of Joint Defense and Economic

Cooperation between the States of the Arab League 1950
181

181 UN Convention on the Law of the Sea

$181 \quad 1982$

$182 \quad$ Article 301

Vienna Convention on the Law of Treaties 1969

185 Article 53

184 Article 64
17

36

163

36 